\title{
ABNORMAL RETURN DAN LIKUIDITAS SAHAM ATAS PENGUMUMAN AKUISISI
}

\author{
Suherman, Riznita Nuraisyah dan Gatot N. Ahmad \\ Fakultas Ekonomi, Universitas Negeri Jakarta \\ Emai:lahmad72nazir@gmail.com
}

\begin{abstract}
The purpose of this study is to analyze the difference of abnormal return and liquidity before and after the announcement of mergers and acquisitions. Abnormal returns are measured with market-adjusted model. Liquidity is measured with trading volume and Amihud Illiquidity ratio. The observation period (event windows) of this research is 11 trading days which 5 trading days before the announcement of the merger and acquisition and 5 trading days after the announcement mergers and acquisitions. Research sample consists of 70 companies which announce merger and acquisition between 2010 and 2014. The results show that 1)there is significant differences of abnormal returns before and after merger and acquisition, and 2)there is no significant differences of stock liquidity before and after merger and acquisition.
\end{abstract}

Keywords: Acquisition, abnormal return, liquidity

Abstrak: Tujuan penelitian ini adalah untuk menganalisis perbedaan abnormal return dan likuiditas saham sebelum dan sesudah pengumuman akuisisi. Pengukuran abnormal return menggunakan market-adjusted model. Pengukuran likuiditas saham menggunakan volume perdagangan dan Amihud's Illiquidity ratio. Periode pengamatan (event windows) penelitian ini selama 11 hari bursa, yaitu 5 hari bursa sebelum pengumuman akuisisi dan 5 hari bursa sesudah pengumuman akuisisi. Sampel penelitian ini adalah 70 perusahaan yang mengumumkan akuisisi antara 2010-2014. Hasil uji hipotesis menunjukkan bahwa 1)terjadi perbedaan abnormal return yang signifikan sebelum dan sesudah akuisisi, dan 2)tidak terdapat perbedaan likuiditas saham yang signifikan pada periode sebelum dan sesudah akuisisi.

Kata kunci: Akuisisi, abnormal return, likuiditas

\section{PENDAHULUAN}

Pasar modal merupakan tempat bagi perusahaan untuk menghimpun dana yang berfungsi untuk membiayai secara langsung kegiatan perusahaan. Selain itu, pasar modal juga dijadikan sebagai tempat berinvestasi bagi investor yang memiliki kelebihan dana. Suryanto (2015) mengatakan bahwa investor yang akan melakukan perdagangan di pasar modal, biasanya mereka akan mendasarkan keputusan mereka pada berbagai informasi yang mereka terima baik melalui publik maupun pribadi. Untuk perusahaan, dalam menghadapi berbagai tantangan perkembangan pasar modal dengan tuntutannya dalam persaingan maka untuk mempertahankan posisi ataupun keunggulan suatu perusahaan, berbagai langkah strategis perlu dilakukan dengan tepat. Salah satu strategi yang dapat dilakukan oleh perusahaan agar perusahaan bisa bertahan atau bahkan berkembang adalah dengan melakukan merger dan akuisisi (Offenberg et al., 2014). Strategi merger dan akuisisi merupakan strategi bisnis yang banyak dipilih oleh perusahaan agar tetap 
unggul dalam persaingan. Motivasi perusahaan melakukan merger dan akuisisi adalah untuk melakukan sinergi dan meningkatkan nilai tambah (value added) bagi seluruh pemegang saham.

Kegiatan merger dan akuisisi di Indonesia sudah mulai berlangsung pada tahun 1970, yang dilakukan oleh bank-bank dengan harapan agar dapat memperkuat struktur modal dan memperoleh keringanan pajak. Di Indonesia aktivitas merger dan akuisisi masih terbilang sedikit jika dibandingkan dengan negara maju. Tabel 1 menunjukkan data yang dimiliki komisi pengawasan persaingan usaha (KPPU) mengenai penilaian aktivitas merger dan akuisisi dari tahun 2010 hingga Agustus 2014 baik pada perusahaan private maupun public menunjukkan jumlah merger dan akuisisi di Indonesia.

Tabe I. Jumlah Merger dan Akuisisi di Indonesia

\begin{tabular}{cccc}
\hline Tahun & Perusahaan Merger & Perusahaan Pengakuisisi & Perusahaan Diakuisisi \\
\hline 2010 & - & 3 & 3 \\
2011 & - & 36 & 52 \\
2012 & 2 & 30 & 40 \\
2013 & - & 58 & 73 \\
$2014^{*}$ & - & 32 & 33 \\
\hline
\end{tabular}

Sumber: Data diolah oleh peneliti, www.kppu.go.id.

Tanda * = bulan Januari sampai Agustus

Pengumuman merger dan akuisisi merupakan salah satu jenis pengumuman yang dapat digunakan untuk melihat reaksi suatu pasar. Pengumuman merger dan akuisisi menjadi sebuah informasi yang penting. Peristiwa ini merupakan salah satu informasi yang diserap dan digunakan oleh para pelaku pasar modal untuk memperoleh keuntungan yang diharapkan di masa yang akan datang. Maryati (2012) mengungkapkan bahwa pengumuman merger merupakan salah satu informasi yang secara teoritis dapat menyebabkan perubahan harga dan volume perdagangan saham. Merger bertujuan meningkatkan efisiensi dan likuiditas transaksi saham di pasar modal, sehingga perusahaan memiliki daya saing lebih tinggi. Menurut Febyanti (2014) bahwa pengumuman akuisisi merupakan alat komunikasi kepada pasar mengenai kinerja suatu perusahaan. Hal tersebut dapat diinterpestasikan sebagai suatu sinyal apakah kinerja suatu perusahaan baik atau sebaliknya.

Penelitian yang dilakukan Aritonang, et al (2009) menunjukkan bahwa terjadi penurunan terhadap harga saham sesudah pengumuman merger dan akuisisi. Penurunan return saham sesudah pengumuman kemungkinan lebih disebabkan informasi merger dan akuisisi direspon investor sebagai informasi yang tidak dapat memberikan keuntungan atau merupakan berita buruk sehingga ketertarikan investor terhadap saham menurun, dengan tidak adanya ketertarikan terhadap saham tersebut harga saham berangsur-angsur menjadi turun dan berdampak pada menurunnya return saham. Perubahan harga saham mengindikasikan besarnya kemakmuran yang diperoleh para pemegang saham melalui jumlah abnormal return yang mereka terima sebagai dampak pengumuman merger dan akuisisi. Abnormal return saham positif menunjukkan adanya sinyal positif atau kabar baik dari publikasi merger dan akuisisi. Dimana abnormal return positif terjadi jika return sesungguhnya (actual return) lebih besar dari pada return yang diharapkan investor (expected return). 
Rahmadiansyah (2013) mengatakan bahwa dalam pengukuran likuiditas saham menggunakan volume perdagangan saham, volume perdagangan yang meningkat karena peningkatan permintaan, maka peristiwa tersebut merupakan kabar baik, sedangkan jika volume peningkatan volume perdagangan yang meningkat karena peningkatan penjualan, maka dapat diartikan bahwa peristiwa tersebut merupakan kabar buruk bagi pelaku pasar.

Dalam penelitian yang dilakukan Amihud (2002) pengukuran likuiditas saham yang diukur menggunakan Amihud Illiquidity menunjukkan bahwa dari waktu ke waktu, pasar yang illikuid secara positif berdampak pada tingkat pengembalian yang lebih di pasar saham atau yang dikenal dengan sebutan illiquidity premium. Tidak secara time series saja, tetapi secara cross section juga terbukti bahwa setiap saham yang tidak likuid maka akan menunjukkan hasil tingkat pengembalian yang tinggi.

Berbeda dengan penelitian sebelumnya, penelitian kami menggunakan pengukuran tambahan untuk menghitung likuiditas saham yaitu menggunakan Amihud Illiquidity dalam melihat reaksi pasar atas pengumuman akuisisi. Lebih jauh, penelitian ini menggunakan period terkini yaitu tahun 2010 sampai dengan 2014. Hasil penelitian ini menunjukkan bahwa abnormal returns signifikan terjadi, namun likuiditas tidak berbeda terjadi sebelum dan sesudah akuisisi.

Selanjutnya ditulis mengenai landasan teori di bagian dua, metode penelitian bagian tiga, hasil di bagian empat dan kesimpulan serta saran di bagian lima.

\section{KAJAIN TEORI}

\section{Merger dan Akuisisi}

Menurut Peraturan Pemerintah Republik Indonesia No. 27 Tahun 1998 Merger adalah perbuatan hukum yang dilakukan oleh satu perseroan atau lebih untuk menggabungkan diri dengan perseroan lain yang telah ada dan selanjutnya perseroan yang menggabungkan diri menjadi bubar. Sedangkan Akuisisi adalah perbuatan hukum yang dilakukan oleh badan hukum atau perseorangan untuk mengambil alih baik seluruh atau sebagian besar saham perseroan yang dapat mengakibatkan beralihnya pengendalian terhadap perseroan tersebut.

Pihak yang masih berjalan atau yang menerima merger dinamakan surviving firm atau pihak yang mengeluarkan saham (issuing firm). Sementara, perusahaan yang berhenti dan bubar setelah terjadinya merger dinamakan merger firm. Surviving firm dengan sendirinya memiliki ukuran yang semakin besar karena seluruh aset dan kewajiban dari merger firm dialihkan ke surviving firm.

Akuisisi sering dianggap sebagai investasi pada perusahaan anak, yaitu suatu penguasaan mayoritas saham perusahaan lain, sehingga tercipta hubungan perusahaan induk perusahaan anak. Perusahaan yang sahamnya dimiliki oleh perusahaan lain akan tetap utuh sebagai suatu kesatuan usaha dan sebagai badan usaha yang berdiri sendiri. Jadi, kedua atau lebih perusahaan tersebut tetap berdiri sebagai suatu badan usaha.

\section{Alasan Melakukan Merger dan Akuisisi}

Gitman dan Zutter (2014) mengatakan terdapat beberapa alasan perusahaan melakukan penggabungan baik melalui merger maupun akuisisi, yaitu: Pertama. Pertumbuhan atau diversifikasi. Perusahaan yang menginginkan pertumbuhan yang cepat, baik ukuran, pasar saham, maupun diversifikasi usaha dapat melakukan merger maupun 
akuisisi. Perusahaan tidak memiliki resiko adanya produk baru. Selain itu, jika melakukan ekspansi dengan merger dan akuisisi, maka perusahaan dapat mengurangi perusahaan pesaing atau mengurangi persaingan. Kedua. Sinergi. Sinergi dapat tercapai ketika merger menghasilkan tingkat skala ekonomi (economies of scale). Tingkat skala ekonomi terjadi karena perpaduan biaya overhead meningkatkan pendapatan yang lebih besar daripada jumlah pendapatan perusahaan ketika tidak merger. Sinergi tampak jelas ketika perusahaan yang melakukan merger berada dalam bisnis yang sama karena fungsi dan tenaga kerja yang berlebihan dapat dihilangkan. Ketiga. Meningkatkan dana. Banyak perusahaan tidak dapat memperoleh dana untuk melakukan ekspansi internal, tetapi dapat memperoleh dana untuk melakukan ekspansi eksternal. Perusahaan tersebut menggabungkan diri dengan perusahaan yang memiliki likuiditas tinggi sehingga menyebabkan peningkatan daya pinjam perusahaan dan penurunan kewajiban keuangan. Hal ini memungkinkan meningkatnya dana dengan biaya rendah. Keempat. Menambah ketrampilan manajemen atau teknologi. Beberapa perusahaan tidak dapat berkembang dengan baik karena tidak adanya efisiensi pada manajemennya atau kurangnya teknologi. Perusahaan yang tidak dapat mengefisiensikan manajemennya dan tidak dapat membayar untuk mengembangkan teknologinya, dapat menggabungkan diri dengan perusahaan yang memiliki manajemen atau teknologi ahli. Kelima. Pertimbangan pajak. Perusahaan dapat membawa kerugian pajak sampai lebih 20 tahun ke depan atau sampai kerugian pajak dapat tertutupi. Perusahaan yang memiliki kerugian pajak dapat melakukan akuisisi dengan perusahaan yang menghasilkan laba untuk memanfaatkan kerugian pajak. Pada kasus ini perusahaan yang mengakuisisi akan menaikkan kombinasi pendapatan setelah pajak dengan mengurangkan pendapatan sebelum pajak dari perusahaan yang diakuisisi. Bagaimanapun merger tidak hanya dikarenakan keuntungan dari pajak, tetapi berdasarkan dari tujuan memaksimisasi kesejahteraan pemilik. Keenam. Meningkatkan likuiditas pemilik. Merger antar perusahaan memungkinkan perusahaan memiliki likuiditas yang lebih besar. Jika perusahaan lebih besar, maka pasar saham akan lebih luas dan saham lebih mudah diperoleh sehingga lebih likuid dibandingkan dengan perusahaan yang lebih kecil. Ketujuh. Melindungi diri dari pengambilalihan. Hal ini terjadi ketika sebuah perusahaan menjadi incaran pengambilalihan yang tidak bersahabat. Target firm mengakuisisi perusahaan lain, dan membiayai pengambil-alihannya dengan hutang, karena beban hutang ini, kewajiban perusahaan menjadi terlalu tinggi untuk ditanggung oleh bidding firm yang berminat.

\section{Hipotesis Pasar Efisien}

Hipotesis pasar efisien adalah pasar dimana harga semua sekuritas yang diperdagangkan telah mencerminkan semua informasi yang tersedia. Fama (1970) membagi tiga macam bentuk utama dari efisiensi pasar berdasarkan ketiga macam bentuk dari informasi, yaitu: (1) Efisiensi pasar bentuk lemah (weak form). Pasar dikatakan efisien dalam bentuk lemah jika harga-harga dari sekuritasnya secara penuh mencerminkan (fully reflect) informasi masa lalu. Informasi masa lalu ini merupakan informasi yang sudah terjadi. Bentuk efisiensi pasar secara lemah ini berkaitan dengan random walk theory yang menyatakan bahwa data masa lalu tidak berhubungan dengan nilai sekarang. Jika pasar efisien dalam bentuk lemah, maka harga-harga masa lalu tidak dapat digunakan untuk memprediksi harga saat ini. Hal tersebut berarti bahwa untuk pasar efisien bentuk lemah, investor tidak dapat menggunakan informasi masa lalu untuk 
mendapatkan abnormal return. (2) Efisiensi pasar bentuk setengah kuat (semistrong form). Pasar dikatakan efisien dalam bentuk setengah kuat jika harga-harga sekuritasnya secara penuh mencerminkan (fully reflect) semua informasi yang dipublikasikan (all publicly available information). (3) Efisiensi pasar bentuk kuat (strong form). Pasar dikatakan efisien dalam bentuk kuat jika harga-harga dari sekuritasnya secara penuh mencerminkan (fully reflect) semua informasi yang tersedia termasuk informasi yang privat. Jika pasar efisien dalam bentuk ini, maka tidak ada individual investor atau grup dari investor yang dapat memperoleh keuntungan tidak normal (abnormal return) karena mempunyai informasi private. Investor selalu membutuhkan informasi mengenai kondisi pasar dan kondisi perusahaan yang menjadi tempat investasi investor

\section{Teori Sinyal}

Edward (2012) mengatakan sinyal adalah sebuah tindakan yang diambil oleh manajemen perusahaan yang memberikan petunjuk kepada investor tentang bagaimana manajemen memandang prospek perusahaan. Signalling theory merupakan dorongan faktor ekonomi dari satu unit usaha untuk mengungkapkan satu kejadian secara sukarela. Aktivitas M\&A mempunyai nilai informatif bagi investor sehingga akan mempengaruhi keputusan investasi dalam bentuk perubahan harga saham karena adanya transaksi yang meningkat atau menurun.

Teori sinyal menjelaskan bahwa pemberian sinyal dilakukan oleh manajer untuk mengurangi asimetri informasi. Asimetri informasi terjadi jika salah satu pihak dari suatu transaksi memiliki informasi lebih banyak atau lebih baik dibandingkan pihak lainnya (Brigham dan Daves, 2010). Asimetri Informasi mengasumsikan bahwa manajemen mempunyai informasi yang akurat tentang nilai perusahaan yang tidak diketahui oleh investor luar, dan manajemen adalah orang yang selalu berusaha memaksimalkan insentif yang diharapkannya, artinya manajemen umumnya mempunyai informasi yang lebih lengkap dan akurat dibandingkan pihak luar perusahaan (investor).

\section{Review Literatur dan Hipotesis}

Febyanti (2014) menunjukkan bahwa tidak ada perbedaan return yang signifikan pada saat sebelum dan sesudah pengumuman akuisisi PT. Hanjaya Mandala Sampoerna Tbk. Hal ini disebabkan karena bentuk efisiensi pasar yang setengah kuat yang memungkinkan diperolehnya informasi yang belum dipublikasikan oleh pihak internal perusahaan sehingga investor telah mengantisipasi rencana merger dan akuisisi pada sebelum pengumuman resmi dikeluarkan. Dananjaya dan Wiagustini (2015) menunjukkan bahwa tidak ada perbedaan abnormal return perusahaan yang signifikan sesudah dan sebelum melakukan merger.

Rani et al., (2014) menunjukkan bahwa akuisisi lintas batas menghasilkan keuntungan yang lebih tinggi dari akuisisi domestik. Hal ini dapat dilihat dari abnormal return yang signifikan pada saat sebelum dan sesudah akuisisi. Abnormal return yang signifikan terjadi karena akuisisi lintas batas memiliki informasi asimetri yang lebih tinggi dibandingkan akuisisi perusahaan domestik. Shah dan Arora (2014) menunjukkan bahwa tidak terdapat perbedaan abnormal return yang signifikan pada periode sebelum dan sesudah pengumuman merger dan akuisisi. Hal ini terjadi karena bentuk efisiensi pasar setengah kuat yang membuat investor mengantisipasi rencana merger dan akuisisi pada sebelum pengumuman akuisisi dikeluarkan. 
Sehgal et al (2012) menunjukkan bahwa peristiwa merger dan akuisisi mempengaruhi perubahan nilai abnormal return antara sebelum dan sesudah pengumuman merger dan akuisisi sehingga terdapat perbedaan yang signifikan. Berbeda dengan likuiditas, pengumuman merger dan akuisisi belum mempengaruhi perubahan nilai likuiditas antara sebelum dan sesudah merger dan akuisisi sehingga tidak ada perbedaan yang signifikan. Ramadhariyansyah (2013) menunjukkan bahwa tidak terdapat perbedaan abnormal return yang signifikan terhadap pengumuman akuisisi pada perusahaan akuisitor dan perusahaan target disekitar tanggal pengumuman akuisisi. Hal ini disebabkan ketidaktahuan para investor terhadap motif perusahaan dalam melakukan akuisisi sehingga tidak adanya keberanian investor dalam melakukan spekulasi baik membeli atau menjual saham perusahaan tersebut, sehingga tidak terjadi abnormal return saham yang signifikan.

Auqie (2013) menunjukkan bahwa tidak terdapat abnormal return disekitar tanggal pengumuman merger dan akuisisi bagi bidder firm yang terdaftar di bursa efek indonesia. Hal ini dapat dikarenakan terlalu pendeknya event window yang digunakan sehingga sinergi belum terlihat bagi bidder firm selain itu, abnormal return bukanlah indikator yang cukup kuat untuk mengukur kekayaan yang diciptakan dari peristiwa merger dan akuisisi. Maryati (2012) menunjukkan bahwa kumulatif rata-rata volume perdagangan setelah event lebih besar dibandingkan dengan sebelum event, dan pengumuman merger berpengaruh signifikan terhadap harga dan volume perdagangan saham.

Aritonang et al., (2009) menunjukkan bahwa tidak ada perbedaan yang signifikan antara return saham sebelum dan sesudah pengumuman merger dan akuisisi, hal ini disebabkan karena investor tidak mengetahui motivasi perusahaan melakukan merger dan akuisisi. Hasil pegujian mengindikasikan adanya perbedaan abnormal return saham sebelum dan sesudah merger dan akuisisi yang disebabkan para spekulan yang mencari keuntungan jangka pendek, dimana para spekulan tersebut merupakan orang-orang internal perusahaan. Untuk volume perdagangan saham tidak terdapat perbedaan yang signifikan sebelum dan sesudah pengumuman merger dan akuisisi, hal ini disebabkan informasi yang tidak dapat memberikan sinyal yang positif sehingga tingkat ekspektasi para investor untuk memperoleh return saham sama. Berikut ini adalah tabel matriks dari review penelitian terdahulu:

Tabel 2. Matrik Penelitian Terdahulu

\begin{tabular}{|c|c|c|c|c|}
\hline No & Peneliti & $\begin{array}{l}\text { Sampel dan } \\
\text { Periode }\end{array}$ & Variabel & Hasil \\
\hline 1 & $\begin{array}{l}\text { Aritonang, et } \\
\text { al (2009) }\end{array}$ & $\begin{array}{l}\text { Sampel: } 9 \\
\text { perusahaan } \\
\text { Periode } \\
\text { penelitian: } \\
\text { 2000-2002 }\end{array}$ & $\begin{array}{l}\text { Return, } \\
\text { Abnormal } \\
\text { Return, dan } \\
\text { Volume } \\
\text { Perdagangan } \\
\text { Saham }\end{array}$ & $\begin{array}{l}\text { Tidak ada perbedaan yang } \\
\text { signifikan antara return saham } \\
\text { sebelum dan sesudah } \\
\text { pengumuman merger dan akuisisi. } \\
\text { Terdapat perbedaan pada nilai } \\
\text { rata-rata abnormal return sebelum } \\
\text { dan sesudah merger dan akuisisi. } \\
\text { Tidak terdapat perbedaan yang } \\
\text { signifikan atas volume } \\
\text { perdagangan saham sebelum dan } \\
\text { sesudah pengumuman merger dan } \\
\text { akuisisi. }\end{array}$ \\
\hline
\end{tabular}




\section{Lanjutan Tabel 2}

\begin{tabular}{|c|c|c|c|c|}
\hline 2 & $\begin{array}{l}\text { Febyanti } \\
(2014)\end{array}$ & $\begin{array}{l}\text { Sampel: } 1 \\
\text { perusahaan } \\
\text { Periode } \\
\text { penelitian: } \\
2005\end{array}$ & $\begin{array}{l}\text { Return dan } \\
\text { Abnormal } \\
\text { Return }\end{array}$ & $\begin{array}{l}\text { Tidak ada perbedaan yang } \\
\text { signifikan pada saat sebelum dan } \\
\text { sesudah pengumuman akuisisi PT. } \\
\text { Hanjaya Mandala Sampoerna } \\
\text { Tbk. }\end{array}$ \\
\hline 3 & $\begin{array}{l}\text { Rani, et al. } \\
\text { (2014) }\end{array}$ & $\begin{array}{l}\text { Sampel: } \\
268 \\
\text { perusahaan } \\
\text { domestik } \\
\text { dan } 255 \\
\text { perusahan } \\
\text { cross } \\
\text { border } \\
\text { Periode } \\
\text { Penelitian: } \\
\text { 2003-2008 }\end{array}$ & $\begin{array}{l}\text { Abnormal } \\
\text { Return }\end{array}$ & $\begin{array}{l}\text { Terdapat perbedaan abnormal } \\
\text { return yang signifikan antara } \\
\text { sebelum dan sesudah akuisisi. } \\
\text { Akuisisi lintas batas } \\
\text { menghasilkan return yang lebih } \\
\text { besar daripada akuisisi domestik. }\end{array}$ \\
\hline
\end{tabular}

4 Sehgal, et al (2012)

5 Shah dan Arora (2014)

Sampel: 37 perusahaan Periode penelitian: Mei 2013 September 2013

6 Maryati (2012) Sampel: 45 perusahaan Periode penelitian: 2006-2007

7 Ramadhariyan Sampel: syah (2013)
118 perusahaan Periode penelitian: 2010-2012
Abnormal

Return dan Likuiditas 09
Terdapat perbedaan yang signifikan rata-rata abnormal return antara sebelum dan sesudah pengumuman merger dan akuisisi.

Tidak terdapat perbedaan yang signifikan rata-rata likuiditas sebelum dan sesudah pengumuman merger dan akuisisi.

Abnormal

Return

Tidak terdapat perbedaan abnormal return yang signifikan pada periode sebelum dan sesudah pengumuman merger dan akuisisi
Harga Saham dan Volume Perdagangan Saham

Abnormal Return
Pengumuman merger berpengaruh signifikan terhadap harga dan volume perdagangan saham. 


\section{Lanjutan Tabel 2}

\begin{tabular}{|c|c|c|c|c|}
\hline 8 & Auqie (2013) & $\begin{array}{l}\text { Sampel: } 32 \\
\text { perusahaan } \\
\text { Periode } \\
\text { penelitian: } \\
\text { 2009-2012 }\end{array}$ & $\begin{array}{l}\text { Abnormal } \\
\text { Return }\end{array}$ & $\begin{array}{l}\text { Tidak terdapat abnormal return } \\
\text { disekitar tanggal pengumuman } \\
\text { merger dan akuisisi bagi bidder } \\
\text { firm yang terdaftar di bursa efek } \\
\text { indonesia. }\end{array}$ \\
\hline 9 & $\begin{array}{l}\text { Dananjaya dan } \\
\text { Wiagustini } \\
\text { (2015) }\end{array}$ & $\begin{array}{l}\text { Sampel: } 8 \\
\text { perusahaan } \\
\text { Periode } \\
\text { penelitian: } \\
\text { 2009-2013 }\end{array}$ & $\begin{array}{l}\text { Abnormal } \\
\text { Return }\end{array}$ & $\begin{array}{l}\text { Tidak ada perbedaan abnormal } \\
\text { return perusahaan yang signifikan } \\
\text { sesudah dan sebelum melakukan } \\
\text { merger. }\end{array}$ \\
\hline
\end{tabular}

Dalam pasar modal, aktivitas merger dan akuisisi memiliki nilai informatif bagi investor sehingga akan mempengaruhi keputusan investasi dalam bentuk perubahan harga saham karena adanya transaksi yang meningkat atau menurun. Rahmadiansyah (2013) mengatakan bahwa abnormal return terjadi karena naik turunnya saham karena reaksi pasar terhadap pengumuman merger dan akuisisi. Jika pasar bereaksi positif terhadap pengumuman merger dan akuisisi tersebut maka akan menghasilkan abnormal return positif, begitupula sebaliknya jika reaksi pasar terhadap pengumuman merger dan akuisisi tersebut negatif maka akan menghasilkan abnormal return negatif. Aritonang et al., (2009) menyatakan bahwa abnormal return yang mengalami penurunan terjadi karena adanya informasi yang tersebar di pasar sudah merata sehingga para investor memprediksi hal yang sama mengenai tentang motivasi dari perusahaan yang melakukan merger dan akuisisi, yang pada akhirnya tidak ada investor yang mempunyai informasi lebih untuk mendapatkan return diatas normal.

Bagi investor akan menguntungkan jika saham likuid karena lebih mudah ditransaksikan sehingga terdapat peluang untuk mendapatkan capital gain. Bagi emiten sendiri likuiditas saham juga menguntungkan, karena apabila perusahaan menerbitkan saham baru akan cepat terserap pasar, selain itu juga memungkinkan perusahaan terhindar dari ancaman delisting (dikeluarkan) dari pasar modal. Bila pengumuman merger dan akuisisi mempunyai informasi yang menguntungkan maka akan berpengaruh terhadap saham yang terlihat dari perubahan volume perdagangan saham. Bukti empiris mengenai pengaruh merger dan akuisisi terhadap likuiditas masih mixed. Maryati (2012) menemukan bahwa likuiditas pasca merger dan akusisi berbeda dengan likuiditas sebelum merger dan akuisisi. Namun Sehgal et al (2012) tidak menemukan perbedaan likuiditas antara sebelum dan sesudah merger dan akuisisi.

Berdasarkan uraian diatas, peneliti menganalisis perbandingan abnormal return dan likuiditas saham yang diproksikan oleh trading volume activity dan Amihud's illiquidity ratio sebelum dan sesudah akuisisi di Indonesia.

Berdasarkan uraian diatas, maka hipotesis penelitian ini dinyatakan sebagai berikut:

$\mathrm{H}_{1}$ : Terdapat perbedaan abnormal return saham yang signifikan pada periode sebelum dan sesudah pengumuman akuisisi perusahaan yang terdaftar di Bursa Efek Indonesia tahun 2010-2014.

$\mathrm{H}_{2}$ : Terdapat perbedaan likuiditas saham yang signifikan pada periode sebelum dan sesudah pengumuman akuisisi perusahaan yang terdaftar di Bursa Efek Indonesia tahun 2010-2014. 


\section{METODE}

Periode pengamatan (event windows) yang digunakan dalam penelitian ini adalah 11 hari bursa, yaitu 5 hari bursa sebelum pengumuman akuisisi (n-5 sampai n-1) dan 5 hari bursa setelah pengumuman akuisisi $(\mathrm{n}+1$ sampai $\mathrm{n}+5)$ yang bergantung pada listing date. Listing date adalah tanggal pengumuman akuisisi yang tercatat di BEI dari masing-masing sampel.

Operasionalisasi Variabel Penelitian. Abnormal Return. Abnormal return merupakan selisih antara return saham sesungguhnya (actual return) dengan return saham yang diharapkan (expected return). Dalam penelitian ini abnormal return ( $\left.\mathrm{AR}_{\mathrm{it}}\right)$ harian individual dihitung dengan menggunakan market adjusted model dengan rumus:

$$
\mathrm{AR}_{\mathrm{it}}=\mathrm{R}_{\mathrm{it}}-\mathrm{R}_{\mathrm{mt}}
$$

dimana: $\mathrm{AR}_{\mathrm{it}}=$ abnormal return saham i pada hari $\mathrm{t} ; \mathrm{R}_{\mathrm{it}}=$ actual return saham i pada hari $\mathrm{t} ; \mathrm{R}_{\mathrm{mt}}=$ expected return pasar pada hari $\mathrm{t}$;

Harga saham yang diperdagangkan dihitung menggunakan return saham sesungguhnya (actual return). Actual return saham diperoleh dengan mencari selisih antara harga saham penutupan harian dikurangi harga saham hari sebelumnya kemudian dibagi dengan harga saham hari sebelumnya. Menghitung actual return:

$$
\mathbf{R}_{\mathrm{it}}=\frac{\boldsymbol{P}_{i t}-P_{i t-1}}{P_{i t-1}}
$$

dimana: $\mathrm{P}_{\mathrm{it}}=$ harga saham i pada hari $\mathrm{t} ; \mathrm{P}_{\mathrm{it}}-{ }_{1}=$ harga saham $\mathrm{i}$ pada hari $\mathrm{t}-1 ; \mathrm{R}_{\mathrm{it}}=$ actual return saham i pada hari $\mathrm{t}$

Untuk return IHSG (pasar) yang diharapkan (expected return) secara matematis dapat dituliskan sebagai berikut:

$$
\mathrm{R}_{\mathrm{mt}}=\frac{I H S G_{t}-I H S G_{t-1}}{I H S G_{t-1}}
$$

dimana: $\mathrm{IHSG}_{\mathrm{t}}=\mathrm{IHSG}$ pada hari $\mathrm{t} ; \mathrm{IHSG}_{\mathrm{t}}-1=\mathrm{IHSG}$ pada hari $\mathrm{t}-1 ; \mathrm{R}_{\mathrm{mt}}=$ return pasar pada hari t.

Pengujian abnormal return tidak dilakukan untuk tiap-tiap sekuritas, tetapi dilakukan secara agregat dengan menguji rata-rata abnormal return (average abnormal return) seluruh sekuritas secara cross-section untuk tiap-tiap hari di periode peristiwa. Menghitung rata-rata abnormal return:

$$
\mathrm{AAR}_{\mathrm{t}}=\frac{\sum_{i=1}^{k} A R_{i t}}{k}
$$

dimana: $\mathrm{AAR}_{\mathrm{t}}=$ average abnormal return pada hari ke $\mathrm{t} ; \mathrm{AR}_{\mathrm{it}}=$ abnormal return untuk sekuritas i pada hari ke $\mathrm{t} ; \mathrm{k}$ = jumlah sekuritas yang terpengaruh oleh pengumuman sekuritas

Likuiditas. Dalam penelitian ini likuiditas saham diproksikan oleh trading volume activity (TVA) dan Amihud's illiquidity ratio. 
Trading Volume Activity (TVA). Untuk menghitung volume perdagangan saham diukur dengan:

$$
\text { TVA }=\frac{\text { jumlah saham } \text { i yang diperdagangkan pada waktu t }}{\text { jumlah saham } \text { i yang beredar pada waktu } t}
$$

dimana: TVA = Trading Volume Activity

Amihud's Illiquidity Ratio. Amihud's Illiquidity ratio adalah pengukuran illiquidity yang dikemukakan oleh Amihud (2002). Amihud menekankan bahwa rasio ini mengukur bagaimana harga saham harian bereaksi terhadap trading value of stock. Semakin tinggi nilai ILLIQ menunjukkan tingkat likuiditas saham tersebut rendah, sedangkan semakin rendah nilai $I L L I Q$ maka saham tersebut semakin likuid. Formula yang digunakan untuk mengukur tingkat illikuiditas adalah sebagai berikut:

$$
\operatorname{ILLIQ}_{\mathrm{i}}=\frac{1}{D_{\mathrm{i}}} \sum_{t=1}^{D_{t}} \frac{\left|R_{i \mathrm{id}}\right|}{T V A L_{\mathrm{id}}}
$$

dimana: ILLIQ $_{\mathrm{i}}=$ rasio illiquidity saham $\mathrm{i} ; \mathrm{D}_{\mathrm{i}}=$ jumlah hari perdagangan sample; $\mathrm{R}_{\mathrm{id}}=$ return saham i pada hari $\mathrm{d}$; $\mathrm{TVAL}_{\mathrm{i}}=$ trading value saham $\mathrm{i}$ pada hari $\mathrm{d}$

Untuk menghitung tingkat illikuiditas, hasil dari perhitungan formula ILLIQ dikalikan $10^{6}$ dan ditransformasi kedalam bentuk log natural (ln).

Metode Pengumpulan Data. Penelitian ini menggunakan data sekunder yang diperoleh dari beberapa sumber. Yaitu mengakses situs http://kppu.go.id/ untuk mengetahui perusahaan-perusahaan yang melakukan merger dan akuisisi. Mengakses situs http://idx.co.id/ untuk mendapatkan informasi mengenai perusahaan go public. Sedangkan harga saham harian, IHSG harian, volume perdagangan diperoleh dengan mengakses http://finance.yahoo.com/. Kemudian peneliti menelaah dan mempelajari data-data yang didapat dari sumber-sumber tersebut.

Sampel

Tabel 3. Sampel Penelitian

\begin{tabular}{lcc}
\hline \multicolumn{1}{c}{ Kriteria Sampel } & Perusahaan pengakuisisi & Perusahaan merger \\
\hline $\begin{array}{l}\text { Perusahaan merger dan } \\
\text { pengakuisisi yang terdaftar di }\end{array}$ & 159 & 2 \\
KPPU dan OJK tahun 2010 - & & \\
Agustus 2014 & $(89)$ & $(2)$ \\
Bukan perusahaan Go Public & & \\
yang terdaftar di BEI periode & 70 & 0 \\
2010-Agustus 2014 & 70 & 0 \\
Go Public & & \\
Sample Akhir & & \\
\hline
\end{tabular}

Penentuan sampel dalam penelitian ini menggunakan teknik purposive sampling, dimana populasi yang akan dijadikan sampel penelitian adalah populasi yang memenuhi kriteri sampel sesuai dengan yang dikehendaki oleh peneliti. Kriteria-kriteria sampel yang 
dikehendaki peneliti: (1) Perusahaan yang melakukan merger dan pengakuisisi yang sudah Go Public terdaftar di BEI pada periode 2010-Agustus 2014; (2) Memiliki tanggal Merger dan Akuisisi yang jelas; (3) Tersedianya kelengkapan data.

Uji Hipotesis. Paired Sample T-Test. Pengujian hipotesis ini menggunakan uji statistik berupa uji parametik paired sample t-test. Paired sample t-test digunakan untuk menguji perbedaan antara dua pengamatan. Paired sample t-test digunakan untuk menguji apakah terdapat perbedaan rata-rata abnormal return dan likuiditas saham pada perusahaan pelaku merger dan akuisisi pada saat sebelum dan sestelah merger dan akuisisi dilakukan. Adapun syarat pengambilan keputusan peneriman atau penolakan hipotesis sebagai berikut: (1) Jika probabilitas atau sig. (2-tailed) $\geq$ taraf signifikansi 1\%, 5\% dan 10\% maka tidak terdapat perbedaan yang signifikan antara kedua sampel berpasangan. (2) Jika probabilitas atau sig. (2-tailed) $<$ taraf signifikansi 1\%, 5\% dan 10\% maka terdapat perbedaan yang signifikan antara kedua sampel berpasangan.

Wilcoxon Signed Rank-Test. Wilcoxon Signed Rank-Test merupakan alat uji statistik non parametrik yang digunakan untuk menguji apakah terdapat perbedaan rata-rata abnormal return dan likuiditas saham pada perusahaan pelaku merger dan akuisisi pada saat sebelum dan setelah merger dan akuisisi dilakukan. Adapun syarat pengambilan keputusan penerimaan atau penolakan hipotesis sebagai berikut: (1) Jika nilai Asymp. Sig. (2-tailed) $\geq$ taraf signifikansi $1 \%, 5 \%$ dan $10 \%$ maka tidak terdapat perbedaan yang signifikan antara kedua sampel berpasangan; (2) Jika nilai Asymp. Sig. (2-tailed) $<$ taraf signifikansi 1\%, $5 \%$ dan $10 \%$ maka terdapat perbedaan yang signifikan antara kedua sampel berpasangan.

Analisis Deskriptif. Hasil statistik deskriptif untuk abnormal return dan likuiditas dengan proksi trading volume activity (TVA) dan amihud's illiquidity ratio (ILLIQ) sebelum dan sesudah akuisisi pada perusahaan yang terdaftar di Bursa Efek Indonesia (BEI) didapat dari pengolahan data menggunakan program SPSS 21 yang disajikan pada Tabel 4.

Tabel 4. Statistik Deskriptif

\begin{tabular}{|c|c|c|c|c|c|}
\hline & $\mathrm{N}$ & Minimum & Maximum & Mean & Std. Deviation \\
\hline $\begin{array}{l}\text { Abnormal Return Sebelum } \\
\text { Akuisisi }\end{array}$ & 70 & $-0,0838$ & 0,2579 & 0,0114 & 0,0623 \\
\hline $\begin{array}{l}\text { Abnormal Return Sesudah } \\
\text { Akuisisi }\end{array}$ & 70 & $-0,1463$ & 0,1919 & $-0,0013$ & 0,0525 \\
\hline $\begin{array}{l}\text { Likuiditas Sebelum Akuisisi: } \\
\text { 1. Trading Volume Activity }\end{array}$ & 70 & 0,000017678 & 0,0453 & 0,0085 & 0,0109 \\
\hline $\begin{array}{l}\text { 2. Amihud's Illiquidity } \\
\text { Ratio (Illiq) }\end{array}$ & 70 & $-0,1442$ & 0,0002 & $-0,0021$ & 0,0172 \\
\hline $\begin{array}{l}\text { Likuiditas Sesudah Akuisisi } \\
\text { 1. Trading Volume Activity }\end{array}$ & 70 & 0,000001680 & 0,1089 & 0,0090 & 0,0161 \\
\hline $\begin{array}{l}\text { 2. Amihud's Illiquidity } \\
\text { Ratio (Illiq) }\end{array}$ & 70 & $-0,2000$ & 0,000026 & $-0,0028$ & 0,0239 \\
\hline
\end{tabular}

Berdasarkan Tabel 4 menunjukkan bahwa jika dilihat nilai rata-ratanya terdapat abnormal return negatif sesudah akuisisi dilakukan. Nilai rata-rata abnormal return negatif menunjukkan bahwa return saham emiten sesudah akuisisi lebih kecil 
dibandingkan return pasar. Selain itu, abnormal return sebelum dan sesudah akuisisi memiliki nilai standar deviasi yang jauh diatas nilai rata-rata. Hal ini menunjukkan bahwa abnormal return selama periode mengalami fluktuasi dan bervariasi.

Nilai minimum abnormal return sebelum akuisisi pada penelitian ini adalah -0,0838 yang dimiliki oleh PT. Harum Energy Tbk atas pengumuman akuisisi pada tanggal 2 Juli 2013, hal ini disebabkan alasan pengambilalihan saham dalam PT Karya Usaha Pertiwi oleh PT Harum Energy Tbk untuk menambah cadangan batubara dalam rangka peningkatan kapasitas produksi menyebabkan perusahaan ini mendapat sentimen negatif dari para investor. Sedangkan nilai maksimum abnormal return sebelum akuisisi pada penelitian ini adalah 0,2579 dimiliki oleh PT Sugih Energy Tbk atas pengumuman akuisisi pada tanggal 9 November 2012, tujuan akuisisi saham dengan International Mineral Resources Inc direspon positif oleh investor, hal ini disebabkan PT. Sugih Energy Tbk sebelum akuisisi mengumumkan harapan produksi dari aset ini akan segera berpengaruh dalam neraca keuangan dan berpengaruh positif pada performa keuangan PT Sugih Enery Tbk untuk tahun buku 2013.

Untuk nilai minimum abnormal return sesudah akuisisi pada penelitian ini adalah 0,1463 dimiliki oleh PT Indospring Tbk atas pengumuman akuisisi pada tanggal 30 September 2013, hal ini terjadi karena pengumuman akuisisi tidak direspon positif oleh investor sehingga membuat expected return lebih besar dari actual return. Sedangkan nilai maksimum abnormal return adalah 0,1919 dimiliki PT Bhakti Capital Indonesia Tbk atas pengumuman akuisisi pada tanggal 10 Januari 2012. PT Bhakti Capital Indonesia Tbk adalah perusahaan investasi yang bergerak di sektor jasa keuangan terintegrasi yang bermaksud melakukan diversifikasi usaha di bidang asuransi, sehingga dengan pengambilalihan PT Jamindo General Insurance, selain diharapkan dapat memberikan dampak positif bagi perkembangan usaha PT Bhakti Capital Indonesia Tbk ternyata dapat memberikan nilai tambah bagi pemegang saham.

Dalam penelitian ini likuiditas dihitung menggunakan dua proksi yaitu TVA dan ILLIQ. Jika dilihat dari nilai rata-rata TVA sesudah akuisisi sebesar 0,00908 lebih besar dibandingkan dengan nilai rata-rata TVA sebelum akuisisi sebesar 0,00855. Hal ini menunjukkan bahwa berdasarkan nilai rata-rata TVA nya rata-rata likuiditas saham mengalami peningkatan. Naiknya volume perdagangan merupakan kenaikan aktivitas jual beli para investor di bursa saham. Semakin meningkat volume penawaran dan permintaan suatu saham, semakin meningkat volume perdagangan saham, hal ini menunjukkan semakin diminatinya saham tersebut oleh investor atau masyarakat. Standar deviasi TVA sebelum dan sesudah akuisisi lebih besar dari nilai rata-ratanya.

Selain itu nilai rata-rata ILLIQ sebelum akuisisi sebesar -0,00218 lebih besar dibandingkan nilai rata-rata $I L L I Q$ sesudah akuisisi sebesar -0,00288. Hal ini menandakan bahwa likuiditas saham sesudah akuisisi meningkat karena rata-rata ilikuiditas menurun. Penyataan ini sesuai dengan Amihud (2002) yang mengatakan semakin tinggi nilai ILLIQ menunjukkan tingkat likuiditas saham tersebut rendah, sedangkan semakin rendah nilai ILLIQ maka saham tersebut semakin likuid.

Nilai minimum likuiditas saham sebelum dan sesudah akuisisi baik proksi TVA maupun ILLIQ dimiliki oleh PT Bhakti Capital Indonesia Tbk yang sekarang dikenal dengan PT MNC Kapital Indonesia atas pengumuman akuisisi pada tanggal 11 Januari 2011. Pengambilalihan saham yang dilakukan oleh Bhakti Capital dengan tujuan diversifikasi usaha di bidang asuransi, sehingga dengan pengambilalihan saham UOB Life 
diharapkan memberikan dampak positif bagi perkembangan usaha Bhakti Capital dinilai negatif oleh investor. Hal ini bisa disebabkan karena Bhakti Capital yang bergerak pada sektor jasa keuangan, pertama kalinya mengakuisisi di bidang asuransi sehingga membuat investor tidak ingin mengambil resiko.

Nilai maksimum likuiditas saham sebelum akuisisi menggunakan proksi TVA pada nilai 0,04539 dimiliki oleh PT Astra International Tbk atas pengumuman akuisisi pada tanggal 27 Desember 2010, hal ini disebabkan penilaian terhadap pemberitahuan pengambilalihan saham perusahaan PT General Electric Services oleh PT Astra International Tbk merupakan sinyal positif bagi investor, sehingga membuat investor tertarik. Akan tetapi pada nilai maksimum likuiditas saham sesudah akuisisi dengan proksi yang sama yaitu TVA tidak dimiliki oleh PT Astra International Tbk, melainkan dimiliki oleh PT Cowell Development Tbk atas pengumuman akuisisi pada tanggal 11 Desember 2012. IHSG yang mencapai rekor terbaru sepanjang sejarah di level 4.311,31 membuat situasi yang kondusif untuk PT Cowell Development Tbk mengakuisisi PT Plaza Adika Lestari. PT Cowell Development Tbk yang dinilai investor akan menikmati kenaikan signifikan dari sisi aset membuat likuiditas saham menggunakan proksi TVA tinggi. Hal itu sesuai dengan analisis deskriptif diatas yang menyatakan nilai maksimum likuiditas saham sesudah akuisisi mencapai 0,10898 .

Nilai maksimum likuiditas saham sebelum akuisisi menggunakan proksi ILLIQ adalah 0,00021 dimiliki oleh PT Pabrik Kertas Tjiwi Kimia Tbk atas pengumuman akuisisi pada tanggal 10 September 2013. Tujuan penyertaan saham untuk mengembangkan usaha yang dilakukan oleh PT Pabrik Kertas Tjiwi Kimia Tbk dengan PT Oki Pulp \& Paper Mills membuat respon positif bagi investor, sehingga nilai ILLIQ sebelum akuisisi merupakan nilai maksimum. Sedangkan untuk milai maksimum likuiditas saham sesudah akuisisi menggunakan proksi ILLIQ adalah 0,0000264 yang dimiliki oleh PT Bhakti Capital Indonesia Tbk yang sekarang dikenal dengan PT MNC Kapital Indonesia atas pengumuman akuisisi pada tanggal 10 Januari 2012. Semakin tinggi nilai ILLIQ menunjukkan tingkat likuiditas saham tersebut rendah. Pengumuman akuisisi yang dilakukan PT Bhakti Capital Indonesia Tbk membuat dampak harga (price impact of trades) semakin besar pada setiap volume transaksi yang diperdagangkan sehingga membuat nilai maksimum likuiditas saham sesudah akuisisi.

Hasil penelitian ini sesuai pernyataan Edward (2012) yang menyatakan bahwa aktivitas M\&A mempunyai nilai informatif bagi investor sehingga akan mempengaruhi keputusan investasi dalam bentuk perubahan harga saham karena adanya transaksi yang meningkat atau menurun.

\section{HASIL DAN PEMBAHASAN}

Uji normalitas digunakan untuk mengetahui apakah data yang diteliti berdistribusi normal atau tidak normal. Fungsi pengujian normalitas data adalah sebagai alat untuk membuat kesimpulan populasi berdasarkan data sampel. Pengujian normalitas digunakan untuk menentukan alat uji selanjutnya yang digunakan dalam penelitian. Uji normalitas yang digunakan adalah uji kolmogorov-smirnov. Kriteria yang dapat digunakan adalah dengan pengujian dua arah (two tailed test). Penghitungan dengan uji kolmogorov-smirnov menggunakan taraf signifikansi 0,05 . Data dinyatakan berdistribusi normal jika 
signifikansi lebih besar dari 0,05 . Sedangkan data dinyatakan tidak berdistribusi normal jika signifikansi kurang dari 0,05 .

Tabel 5. Uji Normalitas

\begin{tabular}{lcrrrrrr}
\hline & \multicolumn{3}{c}{ Kolmogorov-Smirnov $^{\mathrm{a}}$} & \multicolumn{3}{c}{ Shapiro-Wilk } \\
\cline { 2 - 8 } & Statistic & Df & \multicolumn{1}{c}{ Sig. } & Statistic & Df & \multicolumn{1}{c}{ Sig. } \\
\hline Ar Sesudah-Sebelum &, 087 & 70 &, $200^{*}$ &, 968 & 70 &, 071 \\
Tva Sesudah-Sebelum &, 289 & 70 &, 000 &, 485 & 70 &, 000 \\
Illiq Sesudah-Sebelum &, 489 & 70 &, 000 &, 130 & 70 &, 000
\end{tabular}

*. This Is A Lower Bound Of The True Significance.

A. Lilliefors Significance Correction

Kesimpulan dalam pengujian normalitas data pada Tabel 5 adalah variabel abnormal return memiliki data berdistribusi normal karena nilai signifikansinya lebih besar dari 0,05. Proksi TVA dan ILLIQ memiliki data yang tidak berdistribusi normal karena nilai signifikansinya lebih kecil dari 0,05 .

Pengujian Hipotesis Pertama $\left(\mathbf{H}_{1}\right)$. Uji statistik paired sample t-test digunakan jika variabel penelitian berdistribusi normal. Uji paired samples test variabel abnormal return dengan taraf signifikansi 10\%, secara statistik diperoleh t-hitung sebesar 1,716 dan signifikansi 0,091 yang nilainya lebih kecil dari tingkat signifikansi 0,1. Dengan demikian dapat disimpulkan bahwa $\mathrm{H}_{0}$ ditolak atau dengan kata lain terdapat perbedaan abnormal return yang signifikan pada periode sebelum dan sesudah pengumuman akuisisi.

Perbedaan abnormal return yang signifikan menunjukkan bahwa pengumuman merger dan akuisisi mengandung informasi yang direaksi oleh investor sebagai sinyal positif atau kabar baik, sehingga dapat mengubah preferensi investor terhadap keputusan investasinya. Perusahaan melakukan akuisisi sebagai motif strategis untuk memperoleh skala dan ruang lingkup ekonomi serta memanfaatkan sumber daya dan kemampuan yang tersedia, sehingga perusahaan bisa bertahan atau bahkan berkembang.

Tabel 6. Uji Beda Rata-rata Abnormal Return Sebelum dan Sesudah Akuisisi

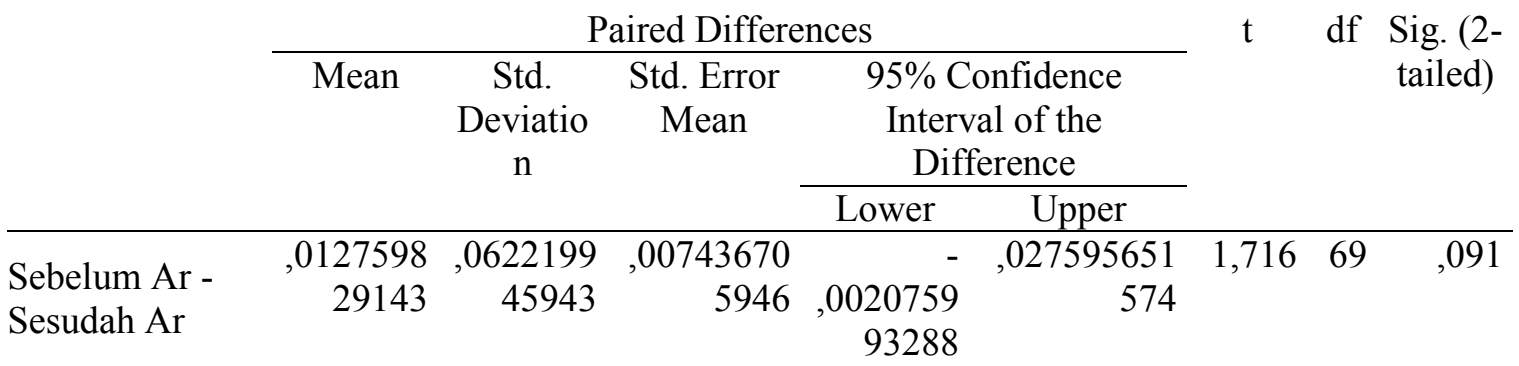

Sehgal et al., (2012) mengatakan abnormal return yang signifikan kemungkinan terjadi karena adanya kebocoran informasi dalam sistem yang memiliki kebijakan implikasi bagi regulator keuangan. Adanya perbedaan abnormal return yang signifikan juga kemungkinan disebabkan oleh para spekulan yang mencari keuntungan jangka pendek, dimana para spekulan tersebut kemungkinan orang-orang internal perusahaan yang mempunyai informasi tentang motivasi perusahaan melakukan akuisisi. Hasil 
penelitian ini sesuai dengan apa yang diteliti oleh Aritonang et al (2009), Rani et al (2014), dan Sehgal et al (2012).

Pengujian Hipotesis Kedua $\left(\mathbf{H}_{2}\right)$. Uji wilcoxon signed rank-test digunakan jika variabel penelitian tidak berdistribusi normal. Berdasarkan uji wilcoxon signed ranks test variabel likuiditas saham dengan proksi TVA, secara statistik diperoleh z-hitung sebesar -0,612 dan signifikansi sebesar 0,541 yang nilainya lebih besar dari taraf signifikansi $10 \%$. Berdasarkan uji wilcoxon signed ranks test variabel likuiditas saham dengan proksi ILLIQ, secara statistik diperoleh $\mathrm{z}$-hitung sebesar -1.279 dan signifikansi sebesar 0,201 yang nilainya lebih besar dari taraf signifikansi $10 \%$.

Dengan demikian dapat disimpulkan bahwa $\mathrm{H}_{0}$ diterima atau dengan kata lain tidak terdapat perbedaan likuiditas saham yang signifikan pada periode sebelum dan sesudah pengumuman akuisisi. Tidak terdapatnya perbedaan likuiditas saham sebelum dan sesudah pengumuman akuisisi menunjukkan bahwa pengumuman akuisisi bukan merupakan informasi yang relevan bagi investor dalam membuat keputusan investasi.

Tabel 7. Uji Beda Trading Volume Activity (TVA) Sebelum dan Sesudah Akuisisi

\begin{tabular}{llrrr}
\hline & & N & Mean Rank & Sum of Ranks \\
\hline & Negative Ranks & $38^{\mathrm{a}}$ & 35,45 & 1347,00 \\
Sesudah Tva - & Positive Ranks & $32^{\mathrm{b}}$ & 35,56 & 1138,00 \\
Sebelum Tva & Ties & $0^{\mathrm{c}}$ & & \\
& Total & 70 & & \\
\hline
\end{tabular}

A. Sesudah Tva $<$ Sebelum Tva; B. Sesudah Tva $>$ Sebelum Tva

C. Sesudah Tva $=$ Sebelum Tva

Test Statistics ${ }^{\text {a }}$

\begin{tabular}{lc}
\hline & Sesudah Tva - Sebelum Tva \\
\hline $\mathrm{Z}$ &,$- 612^{\mathrm{b}}$
\end{tabular}

Asymp. Sig. (2- $\quad$,541

Tailed)

A. Wilcoxon Signed Ranks Test

B. Based On Positive Ranks.

Tabel 8. Uji Beda Amihud Illiquidity (ILLIQ) Sebelum dan Sesudah Akuisisi

\begin{tabular}{llrrr}
\hline & & N & Mean Rank & Sum Of Ranks \\
\hline & Negative Ranks & $39^{\mathrm{a}}$ & 37,46 & 1461,00 \\
Sesudah Illiq - & Positive Ranks & $31^{\mathrm{b}}$ & 33,03 & 1024,00 \\
Sebelum Illiq & Ties & $0^{\mathrm{c}}$ & & \\
& Total & 70 & & \\
& & 70 & & \\
\hline
\end{tabular}

A. Sesudah Illiq < Sebelum Illiq; B. Sesudah Illiq $>$ Sebelum Illiq

C. Sesudah Illiq $=$ Sebelum Illiq 


\begin{tabular}{cc}
\multicolumn{2}{c}{ Test Statistics $^{\mathrm{a}}$} \\
\hline $\mathrm{Sesudah}$ Illiq - Sebelum Illiq \\
\hline $\mathrm{S}$ & \multicolumn{1}{c}{$279^{\mathrm{b}}$}
\end{tabular}

Asymp. Sig. (2- 201

tailed)

a. Wilcoxon Signed Ranks Test

b. Based on positive ranks.

Aritonang et al., (2009) mengatakan hal ini kemungkinan informasi tersebut tidak dapat memberikan sinyal yang positif atau investor menganggap pengumuman akuisisi sebagai pengumuman biasa atau tidak dapat memberikan nilai secara ekonomis sehingga tingkat ekspektasi para investor untuk memperoleh return saham sama. Dengan adanya tingkat ekspektasi yang sama di antara para investor tersebut aktivitas volume perdagangan tidak terdapat perubahan dan saham-saham yang diperdagangkan tidak likuid.

Tidak adanya reaksi pasar yang signifikan atas pengumuman akuisisi, merefleksikan bahwa pelaku pasar (investor) telah mengantisipasi peristiwa ini sebagai akibat dari krisis global, sehingga mereka tidak terburu-buru untuk melakukan aktivitas jual-beli saham. Volume perdagangan saham yang meningkat karena peningkatan penjualan dapat diartikan bahwa pengumuman akuisisi tersebut merupakan kabar buruk bagi pelaku pasar.

Berdasarkan nilai signifikansi proksi ILLIQ tidak terdapat perbedaan tingkat ilikuiditas saham, Hal ini mengindikasikan bahwa akuisisi hanya meningkatkan jumlah lembar saham yang beredar dan tidak memiliki nilai ekonomis.

Penelitian ini berbeda dengan penelitian yang dilakukan oleh Maryati (2012) dimana investor bereaksi positif terhadap event ekonomi yang terjadi yaitu pengumuman merger BEJ dan BES sehingga memperoleh hasil yang signifikan pada volume perdagangan saham. Sedangkan hasil penelitian ini mendukung Aritonang et al., (2009), Sehgal et al., (2012) dan Pustaka et al., (2013) bahwa tidak terdapat perbedaan likuiditas saham sebelum dan sesudah pengumuman akuisisi.

\section{PENUTUP}

Kesimpulan. Salah satu cara perusahaan meningkatkan daya saingnya adalah melakukan akuisisi. Akuisisi adalah mengambil alih baik seluruh atau sebagian besar saham perusahaan. Penelitian ini menunjukkan bahwa terjadi perbedaan abnormal returns sebelum dan sesudah akuisisi. Pasar bereaksi terhadap pengumuman akuisisi. Akan tetapi, tidak terdapat perbedaan likuiditas baik ketika diukur oleh volume perdagangan dan Amihud Illiquidity sebelum dan sesudah akuisisi.

Saran. Metode untuk mencari abnormal return dalam penelitian ini menggunakan market-adjusted model yang mungkin kurang akurat untuk menaksir abnormal return yang sesungguhnya. Penelitian selanjutnya dapat menggunakan metode lain seperti meanadjusted model atau market model. Dalam peneliti ini terdapat keterbatasan jumlah data, diharapkan agar peneliti selanjutnya dapat memperbanyak jumlah data. Lebih jauh, penelitian berikutnya dapat memperpanjang periode pengamatan abnormal return. 


\section{DAFTAR RUJUKAN}

Amihud, Yakov. (2002) "Illiquidity and Stock Returns: Cross Section and Time-Series Effects”, Journal of Financial Markets. p.31-56.

Aritonang, Slamat Harijono, Atim Dzajuli dan H.M Harry Susanto. (2009) "Analisis Return, Abnormal Return, Aktivitas Volume Perdagangan atas Pengumuman Merger dan Akuisisi", Wacana, 12 (4), 815-827.

Auqie, Vally. (2013) "Dampak Merger dan Akuisisi Terhadap Abnormal Return dan Kinerja Keuangan Bidder Firm di Sekitar Tanggal Pengumuman Merger dan Akuisisi Pada Perusahaan yang Terdaftar Pada Bursa Efek Indonesia Periode 20092012”, Jurnal Ilmiah Mahasiswa Universitas Surabaya, 2 (2), 1-16.

Brigham, E. F., dan P. R. Daves. (2010) Intermediate Financial Management. 10th edition, South-Western Cengage Learning.

Dananjaya, Ida Bagus Gede dan Ni Luh Putu Wiagustini (2015) "Studi Komparatif Abnormal Return Sebelum dan Sesudah Merger Pada Perusahaan di BEI", E-Jurnal Manajemen Unud, 4 (4), 1085-1099.

Edward, M. Yunies, (2012) "Analisis Reaksi Pasar atas Pengumuman Merger dan Akuisisi", Jurnal Dinamika Ekonomi dan Bisnis, 9 (1), 1-16.

Fama, Eugene. (1970) "Efficient Capital Markets: A Review of Theory and Empirical Work", Journal of Finance, 25 (2), 383-417

Febyanti, Shabrina. (2014) "Analisis Reaksi Pasar Sebelum dan Sesudah Pengumuman Akuisisi PT. Hanjaya Mandala Sampoerna TBK”, Jurnal Ilmu Manajemen, Vol. 2, p.104-113.

Gitman, L. J., dan Chad Zutter, (2014) Principles of Managerial Finance, Prentice Hall, edisi 14.

Maryati, Ulfi. (2012) "Pengaruh Pengumuman Merger Bursa Efek Jakarta dan Bursa Efek Surabaya Terhadap Harga dan Volume Perdagangan", Jurnal Akuntansi \& Manajemen, 7 (1), 15-29.

Offenberg, D., Miroslava S., dan H. Gregory Waller. (2014) "Who Gains From Buying Bad Bidders?", Journal of Financial and Quantitative Analysis, vol. 49, issue 2, p.513-540

Pustaka, I Gede Abdi dan Made Rusmala Dewi. (2013) “Analisis Perdedaan Likuiditas Saham dan Abnormal Return Sebelum dan Sesudah Right Issue Pada Perusahaan Go Public di Bursa Efek Indonesia", Jurnal Ekonomi, 16 (1), 2225-2241.

Rani, Neelam, Surendra S. Yadav dan P. K. Jain, (2014) "Impact of Domestic and CrossBorder Acquisitions on Acquirer Shareholders' Wealth: Empirical Evidence from Indian Corporate", International Journal of Business and Management, 9 (3), 88110.

Ramadhariyansyah, Hendra. (2013) "Dampak Pengumuman Akuisisi Terhadap Abnormal Return Saham Akuisitor dan Target”, Jurnal Ilmu \& Riset Manajemen, 2 (5), 1-20.

Rahmadiansyah, R. Hidayat. (2013) "Analisis Dampak Sebelum, Sesudah Pengumuman Merger dan Akuisisi Terhadap Abnormal Return dan Volume Perdagangan Saham Pada Perusahaan yang Terdaftar di BEI", Jurnal Akuntansi, hal 1-11.

Sehgal, Sanjay, Siddhartha Banerjee dan Florent Deisting. (2012) "The Impact of M\&A Announcement and Financing Strategy on Stock Returns: Evidence from BRICKS Markets, International Journal of Economics and Finance, 4 (11), 76-90. 
Shah, Priyanka dan Parvinder Arora, (2014) "M\&A Announcements and Their Effect on Return to Shareholders: An Event Study", Accounting and Finance Research, 3 (2), $170-190$.

Suryanto. (2015) "Analysis of Abnormal Return Before and After the Announcement of Investment Grade Indonesia", International Journal of Business and Management Review, 3 (1), 11-23. 